\title{
Social Media Impact on Telangana Movement
}

\author{
Dr. M. Yaznasri Manikarnika \\ Academic Consultant, Department of Mass Communication and Journalism, Yogi Vemana \\ University, Kadapa
}

\begin{abstract}
Telangana has been an everlasting and simmering issue for over a period of 41 years projected by the politicians in general and students in particular. The demand for a Separate Telangana State is deeply rooted among all the sections of society in Telangana region. However it is a fact that it continued to be a political issue in one form and succeeded. Social media like Folk Media, Audio cassettes / CDs, Video / Film, Mobile Phone, blogs, wikis, social network services, social book marking, and peer-to-peer networks. Telangana movement websites could connect the Telangana people residing across the nations in attaining separate statehood to Telanagana.
\end{abstract}

\section{INTRODUCTION}

The Telangana issue has been simmering and rocking the entire India for quite a long time. The people of entire Telangana are facing bull with horn by toil and turmoil in pent up feeling of the great are several types of protests in various levels towards achievement of it. Among the protestants students are cynosure to everything. They played a pivotal role in the first rung of the leader of Telangana issue and some of them rang their own bell and some others have set ablaze and self immolation as sacrifice symbol for the achievement of separate statement to Telangana. On December 9, 2009, P. Chidambaram, the Union Minister of Home Affairs announced that the Indian government would start the process of forming a separate Telangana state, pending the introduction and passage of a separation resolution in the Andhra Pradesh assembly. KCR thus ended his 11 day fast, saying from his hospital bed that this was a "true victory of the people of Telangana." The Telangana issue which began as a regional issue became a national issue in as much as it triggered similar demands for separate statehood for Vidarbha in Maharastra, Goorkhaland in West Bengal and Bundelkhand in Uttar Pradesh. Hanumantha Rao(2010) pertinently pointeds out "Statehood for Telangana is a national issue and not just a regional one. This is because it represents the ongoing social change in the country for the empowerment of people through decentralized governance by broadening and deepening the working of our democratic system.

The composition of participation in Separate Telangana agitation since its inception is in question in view of the fact that there was strong feeling that the agitation was being spearheaded mainly by two predominant communities, Reddis and Velamas in Telangana region. But in reality it was the daliths, backward classes, Minorities and oppressed classes who were in the forefront of separate Telangana agitation. The gross negligence of the coverage of these classes by print media and electronic media is reflective of injustices meted out to these classes in every way since independence.

\section{Social Media ImPaCt ON TElangana Movement}

\subsection{Folk Media}

More than 80 percent of the people in Telangana live in the villages and depend upon the agricultural or agrarian economy. To communicate with the intelligibly, Telangana organizations adopted the folk media which is native and intimate to Telangana folk. Folk arts and literature are integral parts of the Telangana culture. Telangana organizations selected the folk media as right and appropriate channels to communicate with rural masses. The poet-singers and artists from Telangana adopted the folk media as persuasive communication to motivate the people Telangana about the exploitation of Andhras. Through Telangana Dhoom-Dham, they brought awareness among the people at the grass roots level and sent the message to every heart and every hut. 


\subsection{Audio cassettes / CDs}

Telangana movement also depended upon the audio cassettes and CDs to disseminate the movement related speeches and songs. Audio cassettes / CDs are widely heard in buses, cars, autos, lorries and trucks and at tea stalls and all kinds of people have listened to these songs umpteen a time. Some of the songs like Amma Telanganama - aakalikekalaganama, Jaya Jay He Telangana, Mandentapotundu Elamanda, Iddaamvidipote- bhoomibaddalavutunda, Avvodivanuv Ayyodivatelangan odikitotipaalodiva and speeches of leaders inspired and motivated the cross sections of Telangana to take part in the movement.

\subsection{Video / Film}

Video CDs are produced on the present plight of Telangana. The movement related documentary production, distribution has been radically opened by the net, peer to peer software, streaming capability, and most recently by innovations in social software that enable greater ease of use in video uploading, tagging, rating and sorting and downloading. Latest developments are the ability to shoot and share video clips via mobile phone, and experiments in collaborative editing. Telangana activists also produced Batakamma cinema.

\subsection{Mobile Phone}

Mobile phones are the multimodal tool par excellence. In Telangana Movement, SMS has been used to organize mass mobilizations, action alerts, public pressure on elected officials, and win political victories. Ringtones of Telangana Songs by mobile service providers like Air-Tel, have been used to enhance and strengthen popular mobilization. Current developments in the use of mobile phones by Telangana movement include the enhanced ability of phones to create and transmit content other than SMS. High quality photo and video capability in the newest generation of mobile phones has led to several software tools that allow people to publish photos, audio, and videos from mobilizations directly to Telangana movement websites. Bulk SMS are also being sent through mobile.

\subsection{Social Software or New Media}

While the definition of social software is contested, most seem to agree that the category includes software tools that allow participation in collective content production, filtering, modification, commentary, and/or distribution, that facilitate community building through connecting people with similar interests, that allow community standing based on participation, reputation, and trust and that involve bottom-up governance styles. These include blogs, wikis, social network services, social book marking, and peer-to-peer networks. Telangana movement websites could connect the Telangana people residing across the nations.

\subsection{Blogs}

Telangana movement websites could connect the Telangana people residing across the nations. Regularly updated, personal or journalistic websites have existed, the term blog has grown in popularity.

\subsection{Social Network Services}

Another type of social software tool that has been used by Telangana movement is social network services. Social Network sites like Face book, Twitter, Orkut and others operate on the principle of networks of trust, enabling connections between groups of people with similar interests, however esoteric, and links between 'friends of friends of friends'.

In the erstwhile Hyderabad state, during the Nizam regime there was only a little importance for telugunews papers and magazines, since the Urdu was the official language. Nevertheless very few newspapers and periodicals published from Telangana like Telugu Patrika edited and published by Oddiraju brothers from Warangal, Neelagiri Patrika from Nalagonda, Golconda Patrika, from Hyderabad, Warangal, Vani and Jandharma from Warangal, Jeevagadda from Karimnagar and Poddu from Nizamabad could not survive by various reasons, particularly the competition from SeemaAndhra media.

Mean while several newspapers and magazines were started by the Telangana activist and organizations like "Ma Telangana" a magazine was launched by Telangana Information Trust, Jai Telangana, Mana Telangana, Telangana Times, Golkonda Times. They were either closed down after 
some time or brought out on and often due to financial troubles. But, the interpersonal communication and the interaction among activists are intrinsically satisfying, generating an effective approach.

When the state of Andhra Pradesh was at cross roads and at this crucial hour, to decide in which directions the state would have to move HMTV provided an opportunity to people of Andhra Pradesh through its 'LIVE SHOW' on "ANDHRA PRADESH DASA-DISA". It created a platform for people of both the regions to express their views and aspirations. It made the world heard them more louldly and clearly than even before. Why are the people of Telangana demanding a SeparateState? What are the injustices meted to them? What advantages would they get through a separate Telangana State? In deed HMTV made it possible for people of Telangana to express their miseries, troubles, agonies, legitimate desires and aspirations to the people of Seemandhra region. At the same time the live show "Andhra Pradesh Dasa - Disa" provided an opportunity for asking various questions; why are the people of Seemandhra demanding that Telangana should not be formed as a Separate State? What Adavantages would they accrue if the sate would keep united? What are the disadvantages to people of Seemandhra if a Separate Telangana was formed? What are their fears? What are their objections ? what are their desires and aspirations ? to make the people of Telangana hear all these issues HMTV gave a wonderful opportunity through the Live - show " Andhra Pradesh Dasa-Disa".

This Live Show created a peaceful, harmonious, friendly and cordial atmosphere to people of both the regions to express mutual opinions, desires and aspirations so as to understand each other.

\subsection{The First Live Show}

HMTV conducted its first live show on "Andhra Pradesh Dasa-Disa" in Hyderabad Jubilee Hall on December 20, 2009 in which the peoples elected representatives, intellectuals and people of all walks of life of both the regions took part in an extensive debate in a cordial atmosphere. This live show made the viewers cling to TVs. At the end of the show, the Chief Editor, Mr. Ramchandra Murthy announced that similar live shows would be conducted in all the twenty three districts of Andhra Pradesh to collect the public opinion on this never ending issue.

\section{CONCLUSION}

The Telangana issue has been simmering and rocking the entire India for quite a long time. Telangana has been an everlasting and simmering issue for over a period of 41 years projected by the politicians in general and students in particular. Social media like Folk Media, Audio cassettes / CDs, Video / Film, Mobile Phone, blogs, wikis, social network services, social book marking, and peer-to-peer networks. Telangana movement websites could connect the Telangana people residing across the nations in attaining separate statehood to Telanagana.

\section{REFERENCES}

[1] Hanumantha Rao, C.H., (2010). Regional Disparities smaller states and statehood for Telangana, Academic Foundation New Delhi.

[2] Padmanabha Rao, P., (2011), "Regional Disparities and Development of Andhra Pradesh : A Comparative Study of Telangana Region", Deep and Deep Publications (P.) Ltd., New Delhi.

[3] Simhadri, S., (2011). " Telangana Region Identity and Statehood Articulation in Telangana", Osmania Journal of Arts, Vol.2, No.2, January - June 2011, Karshak Arts Printers, Hyderabad.

[4] http://www.simplytelangana.com

[5] www.telanganastudents.org

[6] www.etelangana.org.in 